\title{
증상완화목적의 방사선치료
}

이 창 걸

연세대학교 의과대학 강남세브란스병원 방사선종양학과

\section{Palliative Radiotherapy}

Chang Geol Lee, M.D.

Department of Radiation Oncology, Gangnam Severance Hospital, Yonsei University College of Medicine, Seoul, Korea

The aim of palliative radiotherapy (RT) is to control cancer-related local symptoms with minimal radiation reaction. About one third of all radiation treatments are given with palliative intent. Indications for RT in symptom palliation are as follows: Pain from bone metastasis, pressure symptom from brain and spinal cord, obstruction of bronchus, esophagus, superior vena cava and malignant cancer bleeding from bronchus, urinary tract, uterine cervix and rectum. In hospice palliative care, RT is very effective for symptom palliation and improvement of quality of life without influence on survival. (Korean J Hosp Palliat Care 2009;12:1-4)

Key Words: Palliative radiotherapy, Bone pain

\section{서 론}

방사선치료는 완치목적의 치료와 증상완화목적의 치 료 두 가지로 나뉜다. 전체 암환자의 약 $45 \%$ 는 방사선 치료를 받으며 이중 $25 \sim 30 \%$ 는 증상완화목적의 치료를 받고있다. 증상완화목적의 방사선치료는 약물치료로 조 절되지 않는 암성통증, 뇌전이, 척수신경압박, 종양으로 인한 압박으로 상대정맥 증후군, 식도폐쇄, 기도폐쇄, 요로폐쇄 증상, 조절되지 않는 암성출혈 등에서 시행되 며 약 70 80\%의 증상완화율을 나타낸다. 방사선치료 는 종양을 직접적으로 치료하면서 통증을 제거한다는 장점이 있고 비교적 환자에게 부담이 적으면서 통증완 화효과가 높은 장점이 있다. 진통제만을 사용할 경우 병이 진행되면서 진통제의 단계가 높아지거나 증량하 여야 하나 방사선치료로는 통증이 완전 소실되어 진통 제를 중단하거나 혹은 양을 줄일 수 있다. 완치목적의

접수일: 2009년 2월 10일, 승인일: 2009년 2월 16일 교신저자: 이창걸

Tel: 02-2019-3152, Fax: 02-2019-4821

E-mail: cglee1023@yuhs.ac
방사선치료와는 다르게 환자의 전신상태와 급성 혹은 만성 부작용을 고려하여 짧은 기간내 증상조절을 시키 도록 치료계획을 세워야 하며 경제적인 측면도 고려되 어야 한다. ${ }^{1)}$

완화적 방사선치료는 전인적인 치료의 일부분이어야 하며 환자의 가치와 선호도와 일치하여야 하며 객관적 인 자료에 근거하여야 하며 환자는 치료 결정에 참여하 여야 한다.

1일 치료선량으로 통상적인 방사선량(1.8 2 Gy/day) 보다 높은 선량 $(2.5 \sim 5 \mathrm{~Gy})$ 을 선택하고 정상조직의 방사 선 내성을 고려하여 총방사선량은 낮아진다 $(20 \sim 37.5 \mathrm{~Gy} /$ 1 3주). 1 일 방사선량이 높으면 더 많은 종양세포에 손 상을 줄 수 있으나 정상조직의 방사선 부작용의 가능성 도 높아지므로 종양의 특성과 정상조직의 내성을 고려 하여 다양한 방사선치료 계획이 세워지며 환자의 예후 가 나쁠수록 짧게 치료하는 것이 바람직하다.

\section{부위별 증상완화적 방사선치료}

\section{1. 골전이의 방사선 치료}

골전이에 의한 통증은 암성통증에서 가장 흔한 통증 
증후군이다. 골전이를 잘하는 빈도는 유방암, 전립선암, 폐암의 순이며 말기에는 약 $85 \%$ 까지 발견된다고 보고 된다. 그 외 갑상선암, 악성흑색종, 신장암에서 빈도가 높다. 타장기의 전이보다 골전이는 생명에 직접적인 영 향이 없으므로 생존기간이 더 긴 경향이 있다. 암치료 기술의 발달로 장기 생존 환자가 늘고 있으며 따라서 골전이의 빈도도 높아지고 유방암, 전립선암 환자의 경 우 장기 생존하는(중앙생존기간 22.6개월, 29.3개월) 환 자가 많아 효과적인 치료가 요구된다. 골전이로 인한 증상은 좀더 일찍 나타나고 통증 혹은 골절로 인해 65 75\%는 행동장애로 이어질 수 있다. ${ }^{1,2}$

골전이가 있을 때 방사선치료의 효과는 매우 높으며 골전이가 있는 환자의 대부분은 이 생존기간 동안 효과 적으로 통증을 조절할 수 있다. 방사선치료의 목적은 통증을 줄이고 병적골절을 예방하거나 치유과정을 촉 진함에 있다.

환자의 골조직에 암세포가 전이되면 골파괴와 신생 골 형성 두 가지의 현상이 모두 일어나게 되는데 골파 괴는 파골세포(osteoclast)로 인해 일어나고 신생골 형성 은 골모세포(osteoblast)에 의해 일어난다. 골흡수(bone resorption)는 처음에는 암세포에 의해 반응하는 파골세포 에 의한 골용해(osteolysis)가 일어나고 후에 종양자체에 의한 골용해가 일어나 골파괴로 이어진다. 골 전이로 인해 통증을 느끼는 기전은 1) 구조적인 불안정성 2) 골 막의 자극 3) 파골세포에 의한 골용해 4) 종양자체 5) 종 양에 의한 신경손상 6) 종양에서 분비되는 cytokines에 의해 nociceptors의 자극에 의한 것 등으로 설명된다. ${ }^{2)}$

방사선치료로 인해 통증이 조절되는 기전은 아직 완 전히 밝혀져 있지 않으나 종양의 치료로 인한 파골세포 로 인한 골용해 환경을 조절하고 파골세포와 골모세포 의 활성화를 줄이고 궁극적으로 종양의 크기를 줄여 압 박을 감소시킴으로써 통증을 완화시킨다.

1) 국소 방사선치료를 이용한 통증 조절: 흔히 국소적인 골전이의 경우에 시행하며 치료의 결과는 골전이 부위 와 정도, 원발병소의 병리진단, 개개인의 차이(환자의 병 력과 상태) 그리고 다른 치료와의 병용에 따라 다양하 다. 약 80 90\%의 환자에서 통증 조절이 되며, 통증 조 절된 환자의 약 $50 \%$ 에서 통증이 완전히 없어지며 여생 의 $2 / 3$ 정도 기간 동안 통증완화상태를 유지할 수 있다. 방사선치료는 통증의 완화뿐만 아니라 골용해성 병소의 경우 $65 \sim 85 \%$ 에서 골조직의 치유와 재생(reossification)을 유도한다.

방사선치료의 선량, 횟수, 기간에 대해 많은 연구가
되어 왔는데 $8 \mathrm{~Gy}$ 1회 치료와 $30 \mathrm{~Gy} 10$ 회 치료에 대한 비교 연구인 Dutch trial과 RTOG9714 trial이 대표적이다. 이 다기관 연구의 결과를 요약하면 다음과 같다. 1) 8 $\mathrm{Gy} 1$ 회 치료는 통증 완화면에서 $30 \mathrm{~Gy}$ 를 10 회에 치료 하는 것과 차이가 없으며 $20 \sim 24 \mathrm{~Gy} / 5 \sim 8$ 회으로 치료하 는 것과도 차이가 없다. 2) 통증이 다시 재발하여 재치 료하는 경우는 $8 \mathrm{~Gy} 1$ 회 치료가 2 3배 높았다. 3) 치료 에 대한 반응은 초기 통증지수가 낮은 경우가 더 좋았 는데 통증이 심하면 반응률이 떨어져 초기치료가 더 효 과적이다. 4) 방사선량을 높이더라도 통증완화와 상관 관계가 없었다. 따라서 유방암, 전립선암과 같이 장기생 존이 가능한 종양의 경우 암이 다시 자랄 가능성이 높 으므로 1 회 치료보다는 2 주간 10 회 이상의 치료가 더 바람직하다. ${ }^{3,4)}$

전립선암과 같이 전이되어도 장기 생존이 가능한 경 우 이전에 치료를 받았던 부위에 다시 방사선치료를 하 는 경우가 발생하는데 $58 \%$ 까지 보고되고 있다. 이때 주 의하여야 할 것은 모의치료 필름, 피부 표식, 사진촬영, 치료확인사진 등을 잘 확인하여 치료인접부위 혹은 동 일부위 치료 시 척수와 같은 주요장기에 과선량이 들어 가지 않도록 주의해야 한다. 골전이에 의한 통증으로 같은 부위에 방사선치료를 다시 하는 경우가 많지 않은 데 방사선에 의한 부작용을 우려해서 기피하는 경향이 있다. 환자의 예상수명을 고려하여 짧다고 판단되는 경 우 적절한 재치료가 반드시 필요하다. 최근에는 세기조 절방사선치료(IMRT) 혹은 사이버나이프를 이용하여 정 상조직을 보호하고 암조직에 방사선을 집중할수 있어 재치료가 가능하다. ${ }^{2)}$

한편 골 전이 부위에서 발생되는 병적 골절은 저절로 혹은 경미한 손상에 의해 생길 수 있는데 말기 암 환자 에서의 병적 골절은 남아있는 생존 기간 중 고통과 함 께 심각한 삶의 질의 저하를 초래하므로 골절 예방에 주의해야 한다. 특히 하중을 받는 긴 뼈의 경우 방사선 치료만으로 골절 예방은 어려우며 골절 예상치(표 1,2$)$ 가 8 이상인 경우 정형외과적 내고정(internal fixation)을 시행 후 방사선치료를 권장한다.") 예상 잔여 생존 기간 이 적어도 2 개월이 넘는다면 삶의 질을 고려 수술을 권 장한다. 하중을 받는 부위 이외의 병소는 방사선치료로 통증 해소뿐만 아니라 빼재생을 촉진시켜 골절을 예방 할 수 있다.

\section{2) 다발성 골전이에 대한 광범위 방사선치료}

(1) 광역조사면 방사선치료(Wide-Field Radiotherapy); 골 로 전이된 부위가 여러 곳이고 통증이 전신적일 때 방 
표 1. 병적 골절을 예상할 수 있는 지표(Mirels H). ${ }^{5)}$

\begin{tabular}{|c|c|c|c|}
\hline 점수 & 1 & 2 & 3 \\
\hline 부위 & 상지 & 하지 & $\begin{array}{c}\text { 대퇴골돌기주변 } \\
\text { (peritrochanter) }\end{array}$ \\
\hline 통증 정도 & 경미 & 중등도 & 심함 \\
\hline $\begin{array}{l}\text { 방사선 소견 } \\
\text { 크기(\% of shaft) }\end{array}$ & $\begin{array}{l}\text { 모세포성(blastic) } \\
0 \sim 33\end{array}$ & $\begin{array}{l}\text { 혼합성(mixed) } \\
34 \sim 67\end{array}$ & $\begin{array}{l}\text { 용해성(lytic) } \\
68 \sim 100\end{array}$ \\
\hline
\end{tabular}

표 2. 골절 지수에 따른 실제 골절 정도.

\begin{tabular}{ccc}
\hline 골절 지수 & 대상 환자 수 & 골절률(\%) \\
\hline 7 이하 & 30 & $0 \sim 5$ \\
$8 \sim 9$ & 19 & $33 \sim 57$ \\
10 이상 & 18 & 100 \\
\hline
\end{tabular}

사선반신조사를 시행해 볼수 있으며 또한 골전이 이외 의 많은 장기로 전이되어 유발되는 통증에도 적응이 된 다. 골수의 약 $50 \%$ 이상 포함되는 광역 즉 상반신 $(6 \mathrm{~Gy})$, 하반신, 중반신 $(8 \mathrm{~Gy})$ 에 1회 치료하는 방법으로 골수기 능은 빠른 시일 내 회복 가능하다. 통증완화는 치료 종 료 후 24 48시간 내에 40 50\%에서 얻어지고 전체의 완화율은 80 90\%, 완전 소실은 20 40\% 정도이다.

광역조사면 치료는 국소적 방사선치료를 수 차례 번 거롭게 하는 것보다 통증완화 효과면에서 떨어지지 않 으면서 1 회 치료라는 편의성이 장점이다. 추가 치료가 필요한 경우 3주 후 골수기능이 회복될 때 나머지 반신 에 대해 치료를 시행한다. 부작용을 줄이기 위해 항구 토제를 사용하고, 폐렴을 예방하기 위해 폐에 대한 부 분적 차폐물을 사용한다. 1 년 추적관찰에서 약 $50 \%$ 의 환자에서 통증이 소실된 상태를 나타내며 부작용은 $10 \%$ 이내이다. 이 치료의 대상 환자는 마약성 진통제에 잘 반 응하지 않는 다발성 골전이 환자로 75세 이하, Karnofsky 수행도 70 이상, 잔여생존이 적어도 6 주 이상 예상 되 고, 적절한 골수 기능, 신장기능, 간기능을 유지하면서 상반신치료의 경우 심장경색의 병력이 없어야 한다. ${ }^{2,6)}$

(2) 방사성동위원소치료; 여러 부위에 통증을 동반한 골모세포성 전이를 나타내는 전립선암이나 유방암의 경우 몇 가지 방사성동위원소는 골형성 부위에 집중되 어 방사선을 조사함으로써 효과적인 치료가 가능하다. Strontium-8을 이용한 치료시 통증소실이 약 $50 \sim 60 \%$ 정 도로 보고되고 있으며 Rhenium-186과 Samarium-153 phosphonate chelates도 국제적 임상시험에서 65 80\%의 반응 율을 나타내었다. 동위원소치료로 인한 주된 부작용은 골수억제인데 백혈구, 혈소판치의 30 50\%가 감소되었
다고 보고되었다. 이러한 방사성동위원소 약제들의 큰 장점은 1 회의 주사만으로도 편리하게 광범위한 골전이 의 통증조절에 사용되는 것이며 단점은 고가의 재료비 와 통증의 재발도 약 $50 \%$ 이상에서 나타날 수 있다는 점이다. ${ }^{2,7)}$

(3) 토모테라피; 토모테라피는 CT형태의 ring gantry속 에 $6 \mathrm{MV}$ 라이낙장치가 있어 360도 모든 방향에서 나선 형으로 회전하며 방사선의 세기를 조절하여 암조직에 방사선을 집중하여 정밀한 방사선치료를 구현하면서 동시에 여러 곳의 병소를 차례대로 치료할 수 있어서 다발성 골전이 치료에 용이하다. 특히 광역조사면 방사 선치료에서는 정상조직에 대해 암과 같은 방사선이 조 사되지만 토모테라피의 경우 정상조직을 보호할 수 있 는 것이 장점이다. Lee 등은 토모테라피를 통해 $76 \%$ 에 서 통증완화효과를 나타내었다고 하였다. ${ }^{8}$

\section{2. 뇌 및 척수신경압박}

종양에 의해 통증을 동반한 뇌 및 척수신경압박은 방 사선치료에 의해 경감될 수 있으며 종양의 국소제어를 위해 2 3주간 30 37.5 Gy를 조사하나 장기생존기간 이 6개월 이상 예상되는 경우 5 7주간 $45 \sim 60 \mathrm{~Gy}$ 를 분 할방사선치료 하는 경우도 있다. 총방사선량은 종양이 방사선에 민감한 정상조직에 얼마나 가까이 있는지에 의해 제한된다.

뇌전이에 대해 방사선치료 시 약 $80 \%$ 에서 두통, 운동 과 감각소실, 의식혼탁의 증세가 호전가능하다. 뇌전이 개수가 3 개 이하이고 $3 \mathrm{~cm}$ 미만인 경우 1 회 치료의 방 사선 수술치료법으로 약 $87 \%$ 의 높은 국소제어율을 나 타낸다.

경막외 척수압박의 임상증상은 하지에 힘이 빠지고, 보행장애, 대소변 장애, 요통이 따르는데 응급진단 후 치 료가 필요하다. 이미 거동이 어렵거나 항문 괄약근에 힘 이 들어가지 않는 경우 예후가 불량하며 치료에 대한 반 응이 높지 않다. Corticosteroid 사용을 시작하며 방사선치 료를 우선적으로 고려하여야 한다. 거동이 가능한 상태 에서 방사선치료를 시작한 경우 $70 \sim 80 \%$ 는 지속적으로 거동이 가능하며 이미 하지 마비가 온 경우 치료를 시작 하면 약 $40 \%$ 만이 거동이 가능하다. 통증이 있는 경우 75\%에서 경감된다. 방사선에 대한 반응도가 떨어지는 신 장암, 육종 등의 경우 종양으로 인한 압박을 빠른 시간 내 해소하기 위해 척추궁절제술(laminectomy)이 우선되어 야 하나 침습적인 방법임을 감안 환자의 전신상태, 잔여 생존기간, 이전에 방사선치료 유무, 척추의 안정성이 문 
제가 되는 경우를 고려하여 결정하는 것이 바람직하다. ${ }^{1)}$

\section{3. 그 외 증상완화 방사선치료의 적응증}

1) 상대정맥증후군: 종양에 의한 상대정맥의 압박으로 인해 혹은 이로 인한 혈전에 의해 발생하며 호흡곤란, 안면부종, 안면홍조, 경정맥 확장, 흥벽정맥 확장, 경부 혹은 상지부종의 증상이 발생된다. 원인으로는 폐암이 $75 \%$, 악성림프종이 $15 \%$ 로 보고되며 방사선치료를 우선 적으로 시행할 경우 증상호전이 빠르다. 3 4 Gy의 방 사선으로 2 4회 치료하여 증상 호전을 시킨 후 통상적 인 방사선치료로 전환하여 치료하며 2주내 $50 \sim 95 \%$ 로 증상완화효과를 나타낸다. ${ }^{1)}$

2) 악성 기관지 폐쇄: 종양으로 기관지 내부가 폐쇄되 거나 외부 압박으로 인해 협소해지면 폐 허탈이 일어나 고 이로 인해 호흡곤란, 폐쇄성 폐렴이 발생된다. 기관 지내 폐쇄의 경우 Iridium-192 동위원소를 이용한 고선 량률 기관지내 근접방사선치료를 시행하거나 기관지외 압박에 의한 경우 체외방사선치료를 시행하여 약 60 $80 \%$ 의 증상완화효과를 나타내고 있다. ${ }^{1)}$

3) 악성 연하곤란: 식도암 혹은 식도주변 림프절전이 로 인해 식도를 압박하여 발생되며 방사선치료로 약 70 $\sim 80 \%$ 의 증상완화효과를 나타내며 종양의 침범정도가 심한 경우 누공의 가능성도 있으므로 주의를 요한다. ${ }^{1}$

4) 그 외: 악성 종양출혈, 악성 요로폐쇄, 악성 간담도 폐쇄로 인한 황달, 악성 림프부종과 같은 경우에도 완 화적 방사선치료는 $70 \%$ 정도에서 증상완화효과를 나타 내고 있다. ${ }^{1)}$

\section{결 론}

호스피스완화의료에서 방사선치료는 비록 생존기간 의 연장에는 영향을 미치지 않으나 환자에게 부담을 최 소화하면서 증상완화효과는 대단히 우수하여 임종시까 지 삶의 질을 유지하는데 큰 역할을 하므로 환자의 상 태, 종양의 민감도, 환자의 선호도를 고려하여 치료를 하고 특히 골전이가 있는 경우 통증조절, 병적골절예방, 척수마비예방을 위해 방사선치료를 우선적으로 고려하 는 것이 바람직하다.

\section{요 약}

방사선치료의 목적은 완치목적 그리고 증상완화목적 두 가지로 나뉜다. 전체 암환자의 약 $45 \%$ 는 방사선치료
를 받으며 이중 $25 \sim 30 \%$ 는 증상완화목적의 치료를 받 고있다. 방사선치료는 비록 생존기간의 연장에는 영향 을 미치지 않으나 증상완화효과는 대단히 우수하며 임 종시까지 삶의 질을 유지하는데 큰 역할을 한다. 증상 완화 방사선치료의 적응증으로는 골전이에 의한 통증, 뇌전이, 척수압박으로 인한 신경학적 증상, 암으로 인한 기관지, 식도, 상대정맥 폐쇄 증상, 기관지, 비뇨생식기 계 직장의 암성출혈 등이다. 이 중 골전이에 대한 치료 가 가장 흔한 적응증이며 통증조절 외에 병적골절예방 및 척수압박예방의 효과를 가지며 약 $70 \sim 80 \%$ 의 증상 완화효과를 나타낸다.

중심단어: 증상완화, 방사선치료, 골전이

\section{참 고 문 헌}

1. Hoskin PJ. Radiotherapy in symptom management. In: Doyle D, Hanks G, Cherny N, Calman K, eds. Oxford textbook of palliative medicine. 3rd ed. New York: Oxford University Press; 2004. p. 239-55.

2. Hartsell WF. Yajni santosh. Palliation of bone metastasis. In Halperin EC. Perez CA. Brady LW, eds. Perez and Brady's principles and practice of radiation oncology. 5th ed. Lippincott Williams \& Wilkins; 2007. p. 1986-99.

3. Steenland E, Leer JW, van Houwelingen H, Post WJ, van den Hout WB, Kievit J, et al. The effect of single fraction compared to multiple fractions on painful bone metastases: a global analysis of the Dutch Bone Metastasis Study. Radiother Oncol 1999; 52(2):101-9.

4. Salazar OM, Rubin P, Hendrickson FR, Komaki R, Poulter C, Newall $\mathrm{J}$, et al. Single-dose half-body irradiation for palliation of multiple bone metastases from solid tumors: final Radiation Therapy Oncology Group report. Cancer 1986;58(1):29-36.

5. Mirels H. Metastatic disease in long bones: a proposed scoring system for diagnosing impending pathologic fractures. Clin Orthop Relat Res 1989;249:256-64.

6. Scarantino CW, Caplan R, Rotman M, Coughlin C, Demas W, Delrowe J. A phase I/II study to evaluate the effect of fractionated hemibody irradiation in the treatment of osseous bone metastases: RTOG 88-22. Int J Radiat Oncol Biol Phys 1996;36 (1):37-48.

7. Tennvall J, Darte L, Lundgren R, el Hassan AM. Palliation of multiple bone metastases from prostatic carcinoma with strontium-89. Acta Oncol 1988;27(4):365.

8. Lee IJ, Seong J, Lee CG, Kim YB, Chang Keum K, Suh CO, et al. Early clinical experience and outcome of helical tomotherapy for multiple metastatic lesions. Int J Radiat Oncol Biol Phys 2008 Dec 10 (in press). 